岩石鉱物鉣床学会誌

65 巻 5 号, 1971 年

\title{
北上山地，白亜紀花㖾岩缶岩類の带状区分*
}

\section{Zonal arrangement of the Cretaceous granitic rocks, Kitakami mountainland}

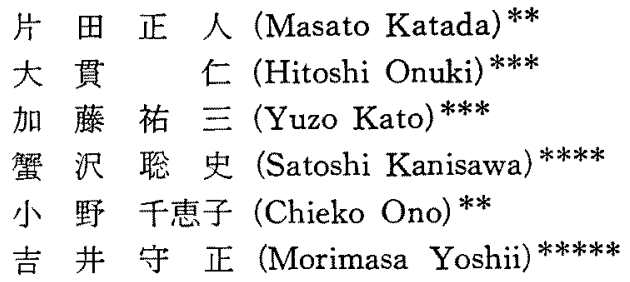

Abstract: The Cretaceous granitic province of the Kitakami mountainland, northeast Japan, are arranged zonally on the basis of the field occurrences, petrography and petrochemistry. The names of the zones and their rock bodies are as follows:

An zone: Kuki, Taro, Oura etc.

$B$ zone: Hashigami, Tanohata, Miyako etc.

C zone: Hiraniwa, Sakai-no-kami etc.

$D$ zone: Ichinohe, Himekami etc.

As zone: Hirota, Kinka-san etc.

E zone: Kurihashi, Goyo-san, Tono, Kesengawa, Hitokabe etc.

F zone: Orikabe, Ojika etc.

G zone: Tabashine, Rifu etc.

The variation of rock facies is remarkable in the $C, D, F$ and $G$ zones and distinct in the An and As zones. Rock bodies belonging to above six zones are small in size. On the other hand, granitic bodies in the B and $\mathrm{E}$ zones are large in size and poor in rock variety.

Petrochemically, $\mathrm{Na}_{2} \mathrm{O}$ contents are higher than $\mathrm{K}_{2} \mathrm{O}$ contents in the $\mathrm{B}$ and $\mathrm{E}$ zones and the great portion of the $\mathrm{An}, \mathrm{As}, \mathrm{C}$ and $\mathrm{F}$ zones. But, in contrast, $\mathrm{K}_{2} \mathrm{O}$ contents in the $\mathrm{D}$ zone are higher than $\mathrm{Na}_{2} \mathrm{O}$ contents. Total alkalies in the $\mathrm{B}$ zone are poor and those in the $\mathrm{D}$ zone are rich.

Probably such three pairs as An and As, C and F, D and G belong to the same groups, respectively.

\footnotetext{
* 昭和 46 年 2 月 日本岩石鉣物鉣床学会にて瀞演

** 地質調查所地質部

**** 東北大学理学部

**** 東北大学教㝨部

$* * * * *$ 地買調查所鉣床部
} 


\section{1. まえがき}

北上山地において，花崗岩資岩数の占める露出面榬は北上山地の全域の約 $1 / 5$ に相当

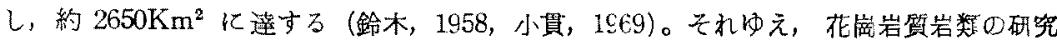
は北上山地の地䝷学的，岩石学的研究において大きな分影を占めるべき課题のひとつであ ろう。これらの花崗岩賀岩類の大部分は白重紀の迸入になるものである。

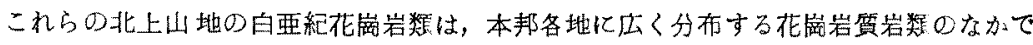
もいくつかの独特な特徴をそなえている。たとえば，貫入後，現在までの間にあまり地読

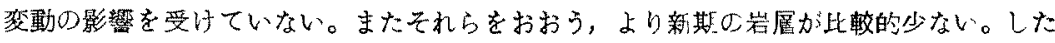
がって貫入時の外形や岩質が注とんどそこなわれず，ほ浪そのまま保たれているものが多 い。これらの岩石は数多くの岩体を形成しているが，岩体の大半は比較的小さいものであ り，最大の遠野岩体でも約 $20 \times 10 \mathrm{Km}$ の面䅡を占めているにす巳゙ないこれらの岩体の 岩資は比較的変化に富み，苦鉄質一珪長筫，深成岩質（中・粗粒，等粒状）一半深成岩賀 (斑岩一恢岩質)，アルカリに䈏むもの一㐋しいものなど，岩体により，部分により，さま ざまな岩相が発淕する。

ここで筆者等がまとめた報告は，これらの多彩な花侖岩質岩体群を現在可能ながり合 理的に区分しょうとする試案である。これは野外観察，顕微鏡的観察および化学分析值等 の総合的筫料供ついて行なったものである。

徉来，このような試死䇟くの研究者によって行われてきた。たとえば渡辺(1950)， 石井・他 (1956)，Sendo (1959)，五十嵧・他 (1961)，柴田（1967）などである。しかし これらの区分は比較的せまい盽围の、著名な、岩体に重点を㧍きすきた場合が多かったし，

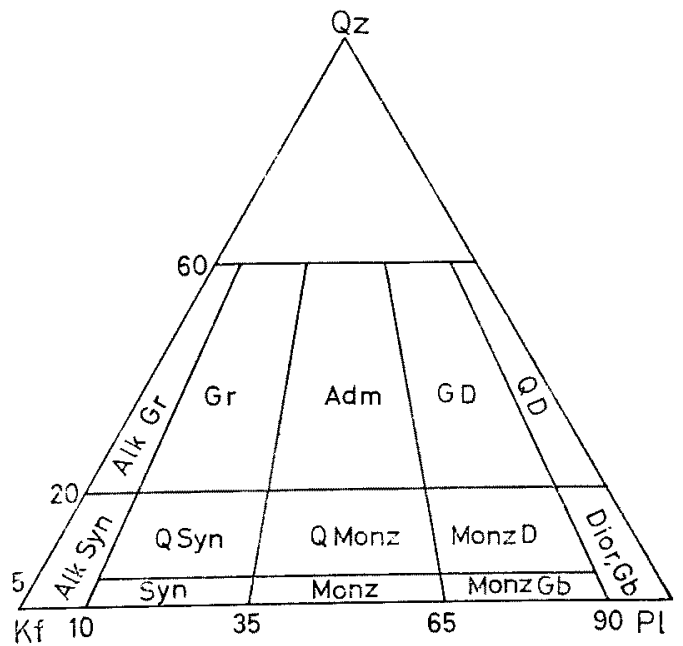

Fig. 1. Qz-Kf-Pl triangular diagram showirg nomenclature of granitic rocks. 
区分の根继が充分とは言えない例もあった。筆者等は北上山地の全域にわたり，岩体の大 きさや分布地域にかかわりなく，広くそして多くの资料を集めることができだてこでこ れらの資料に基づき，徒来の諸資料を参考にしながら，これから述へるような区分を行な oto

なお，北上山地の花崗岩質岩類は所謂 “granitic rocks”としては幅㕕い化学組成をも ち，従来行われている:分類法、では必すしも充分それらの性䝷を表現し得ないが，一応， 花南岩質岩類の命名は Streckeisen（1967）の命名法を一部修正して用いた（第1図）。

\section{2. 花商崖質岩類の区分と主として野外におけろ事夷}

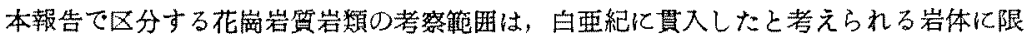
ることとする。Shibata・Miller（1962），河野·植田（1965）によれば，それらの K-Ar

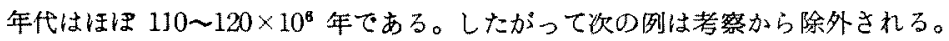

1) 氷上花峛岩質岩数。

口）早池峯・宮守など超塩基性岩類に甠う深成岩数。

八）孤立して露出する時代未群，所属不明の深成岩一半深成岩類。

さて，北上山地の白垔紀花崗岩質岩類を区分した結果は第 2 図に示され，An, B, C, D,

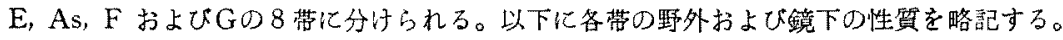

An 帯：久喜，田老，大浦岩体なぼられれ屈する。すでに報告したように（吉井・片 田，1968），これらのの分布域仙陸中層群の分布域である田老带と注とんど一致する。花 崗岩質岩類は小量の石英門緑岩貿の岩石（久吉，田老岩体の一部，本間，1962）とそれを 貫く花峒閃緑岩ないしアダメロ岩があり，後者は多くの場所で花崗斑岩または文象斑岩に 移化する。田老带の西側の境界線すななち田老構造線に沿った部分，たとえぼ久亚東方， 松前沢上流，津軽石南方などでは，軽度ないし中程度のプロトクラスチック組織を示す部 分が見出られる。また, 久慈南東方では, カリ長石>斜長石の花崗岩ないし花崗斑岩が発 達する。この带には他の带と比較して，もっとる珪長質の岩石か引られる。

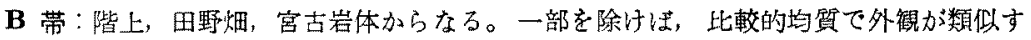
る。後述のように化学組成の变化は比較的乏しい特徴がある。主として中粒で，肉眼的に

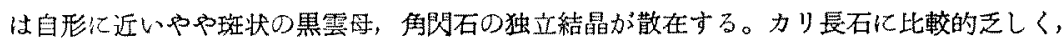
存在する場合も镜下で甚だしく䁲間状である。比較的苦鉄筫の岩相は少なく，花崗聞緑岩 ないし石英閃緑墔が大部分を占める。また所䜊, 壏基性捕獲岩も少ない。この带の分布域

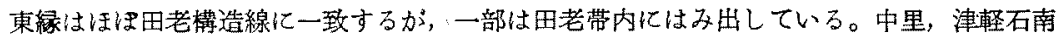
方で An 带の花菵岩買岩類の一部に接触变成作用を与えている。

C 带：平庭，天神森，境の神，称々子森など多数の小岩体が分布する。多くは花嶰閃 緑岩・石英閃緑岩欣いでアダメロ岩であるが，斑䊔岩ないし閃緑岩を佯なうことが珍らし くない。たたしアダメロ岩は平庭岩体より北部の小岩体には極めでしい。個々の岩体内 で岩相瓷化が著しく，周辺部などに細粒相が発避することもある。平庭岩体の一部と転石 しかみあたらないが軽米付近には，モンソ門緑岩ないしモンゾ斑雬岩の存在が認められる。 また角閃石に藷しく富んた角閃石斑栯岩も少なくない。 


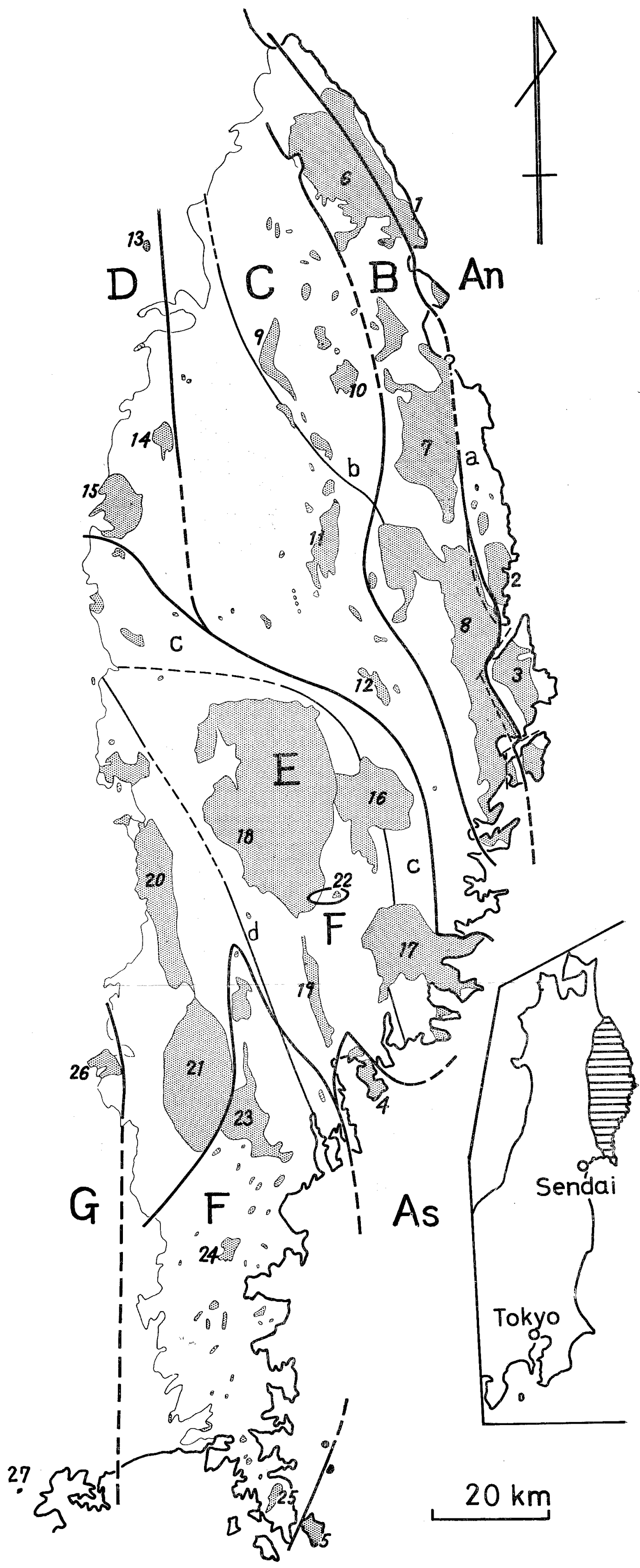

Fig. 2. Zonal arrangement of the Cretaceous granitic rocks, Kitakami mountailand. a. Taro tectonic line, b. Kuzumaki tectonic line, c. Hayachine tectonic belt. d. HizumeKesenmuma tectonic line, 1 27. Granitic bodies (1. Kuki 久蔁, 2. Taro 田老, 3. Oura 大浦, 4. Hirota 広田, 5. Kinkazan 金華山, 6. Hashigami 階上, 7. Tanohata 田野畑, 8. Miyako 宮古, 9. Hiraniwa 平庭, 10. Tenjin-mori 天神森, 11. Sakai-no-kami 境の神, 12. Yayako-mori 称々子森, 13. Ichinohe 一F, 14. Himiko 日神子, 15. Himekami 姫神, 16. Kurihashi 栗橋, 17. Goyo-san 五荣山, 18. Tono 遠野, 19. Kesengawa 気仙川, 20. Hitokabe 人首, 21. Senmaya 千或，22. Akimaru 秋丸，23. Orikabe 折壁，24. Iriya 入谷, 25. Ojika 牡鹿, 26. Tabasine 束稲, 27. Rifu 利府). 


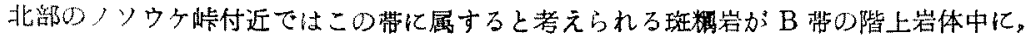
捕獲岩として包有されている事実がある。

D 带：一户，日神子，姫神岩体などがこの带に属する。これらの岩体については，古 くは Kozu (1914)，近藤 (1930) の研究があり，近年では Onuki·Tiba (1964)，增田・

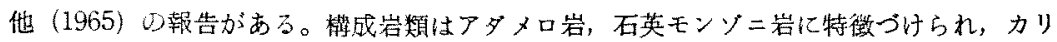
長石に比較的富九でいる。上記の3岩体仙いずれるケンタレン岩を小量伴ゔ。また，黒 雲母単斜輝石岩或い弾斜輝石蝫雲母岩の超苦鉄貿岩類をる伴うことがある。

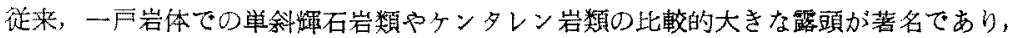
それが一般的性䝷のごとく認儎されているおそれがあるが：この岩体は新生代の地層にお おわれて，岩伟の一部のみが現在簬出しているにすきないことに留意すべきである。事实， 日神子，姫神门雨岩体には上記の岩石の存在は極めて小墨である。

$\mathrm{E}$ 蒂：北上山地の注注中心地城であって，大きな規模の岩体加露出する。各岩体は主

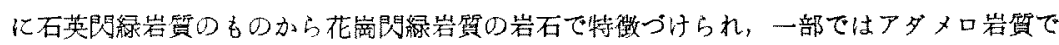

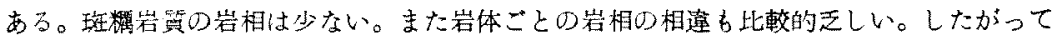

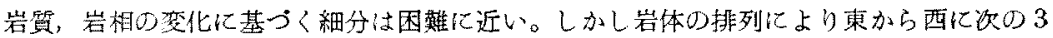
つの亜带に細分することがでる。

1) 栗橋一五葉山(越喜来) 岩体

2) 遠野一気仙川岩体

3) 人首一千㮹岩体

1）はカラートンデックスの高い部分がや〉多く(鈴木，1958），そのわりにはカリ長石 に富んでいる。3）はカリ長石にそしい石英聞緑岩貿の部分が多いなどの性質が指摘できる。 この畚の北東限は早池等槽造带の外縁にほほ一致する。

As 常：厇田岩体と金華山岩体がこれに属する。広田岩体とE带から切りはなした理由 は後述するごとくこの岩体が金華山，気仙川岩体などと異なる点があり，それらと一連の

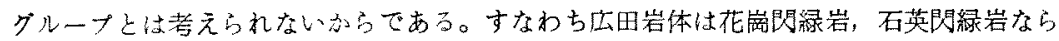

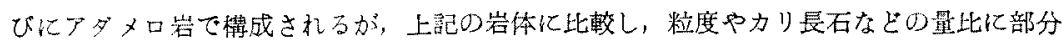
差が藷しい。またカり長石〉石英の $\mathrm{K}_{2} \mathrm{O}$ に比較的䈏んだ部分が少なくない。そして細粒 相が多いなどという野外の観察からもそうであるが，斜唇石の秩序度**や岩石磁気的性

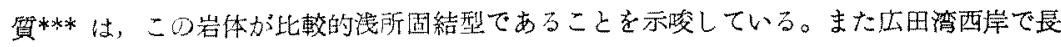
部磁岩などを貫く小岩体も広田岩体の一部である可能性が強いが，これは時にプロトクラ スチック組穖を示している（神户・舅津，1961）。

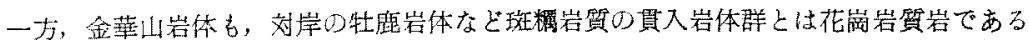

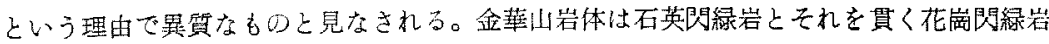
があり，前者の分枝岩体はプロトクラスチック組織を示し，後者の一部は金烡山東岸で花

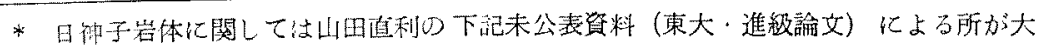
巳い。

N. Yamada (1951), Geology of Yamagata district, Iwate Prefecture.

** 解沢聡史，未公表㗄料䎲よる。

*** 上野宏共, 1971 年岩石銀物鍍床学会総会講演ならびに談話による。 
峷斑岩筫の岩石に移化する。したがって金華山岩体は広田岩体にかなり似た諸点があり， 同一の带往すると考えられる。

F 帯：秋丸，折壁，入谷，牡鹿その他の小岩体群からなる。斑雬岩質のものから花崗

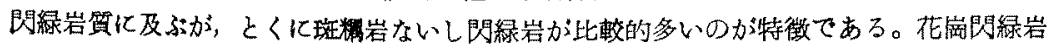
は比較的大きな折壁，内野峠，入谷なとの岩体の一部に限られる。これらの岩体はアダタ 口岩を伴うことがある。また比較的大きな岩体では周辺相として細粒相が発達し，小岩体 はほとんど全体が稩粒相で玡岩質である。F带内には岩脈として角咸石玢岩ないし安山䇹 が多数みられるがこれらといま問題の斑瀮岩類とは明瞭汇区別することができる。なお， 折壁岩体の中心部と石巻北方の曾波神岩体の一部にはカリ長石に富み，石英に元しい岩相

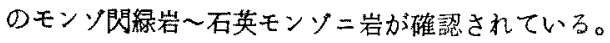

なお，遼野岩体南東の秋丸岩体は細粒ないし中粒の石英聞緑岩であり，岩相の類伿性か らみてF带に属すると思われる。この秋丸岩体に類似する小岩体が酉方の赤羽虾南で遠野 岩体を買いている。また折照岩体がE带の千㮹岩体に接する部分でも，前者は後者にむか つて練粒の周辺相を示している。したがって折壁岩体は千厩岩体の買入後にその位置を占 めたと考えられる。

$\mathbf{G}$ 帯: この带は北上山地の南西端に位置し，新生代の地層におおわれる部分が多く， 分布がはっきりしない。束稲，利府の2岩体はこのG带に属すると考えられる。束稻岩体 は息津 (1955) より後の研究は公表されていない。鼠津䎲よると閃緑岩質のものからアタ メ口岩までのいくつかの岩相があり，力リ長石〉石英のものが多、。苦鉄質から珪長質ま での広範囲の岩石があり， $\mathrm{K}_{2} \mathrm{O}$ 亿富んでいる一般的性質は $\mathrm{F}$ 帯或いはE带の岩体と異な っており，同一視できない。

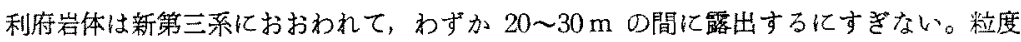
や組成は不均筫であるが，岩質はつダタ口岩ないしモンソ阴緑岩と言える。この岩体と束 稻岩体とを同一の蒂に属すると考えるのは岩質，分布上からみて妥当であるう。

\section{3. 化学的考察}

前項では，北上山地白垔紀花领岩鷿岩類の区分を主として里外ならびに鏡下の資料によ って説明したが，ここでは各带の岩体を嫦成する岩石の化学組成上の特微をいくつかの図 によって示すことにする。

現在までに蓄積された岩石の化学分析資料は約 200 個である。しかしすへて本項の目 的にそのまま利用できるものではなく，次の各項に相当する岩石の化学組成は除外するこ とにする。

1). アブライト,ベグマタイト。

口). 単斜輝岩および類似の岩石。

八). 斜長岩質岩石。

二)、塩基性捕蒦岩，シュリーレンと呼ばれるるの。

ホ)、採取地点がどの蒂に属するか不明のもの。

以上を除くと総利用数は 148 個，うち未公表資料（本報告，附表 1 を含めて） 32 個で ある。 
北上山地，白要紀花崗岩筫岩類の帯状区分

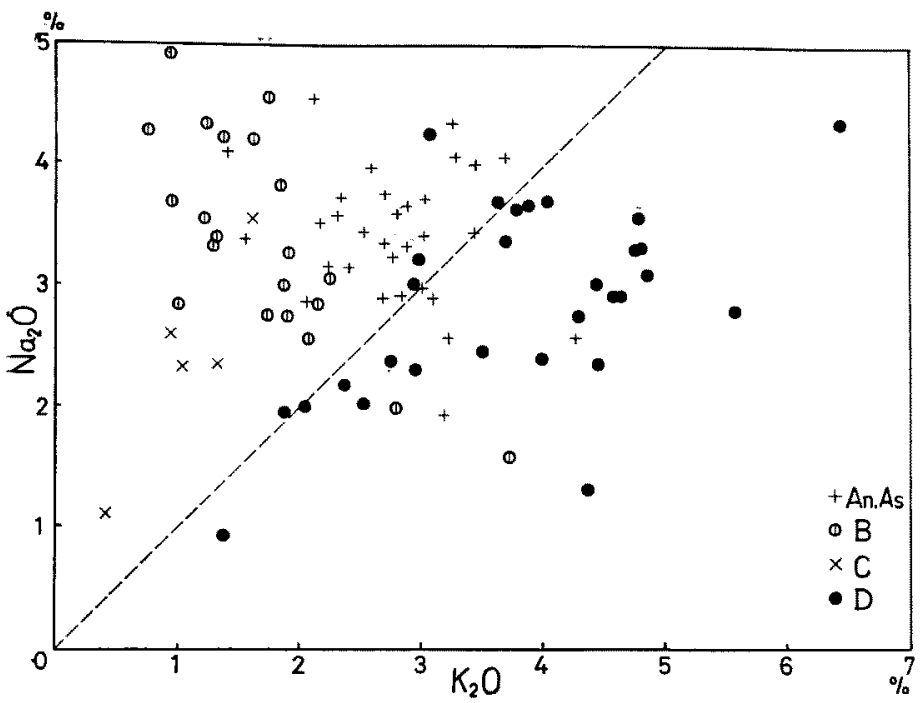

a

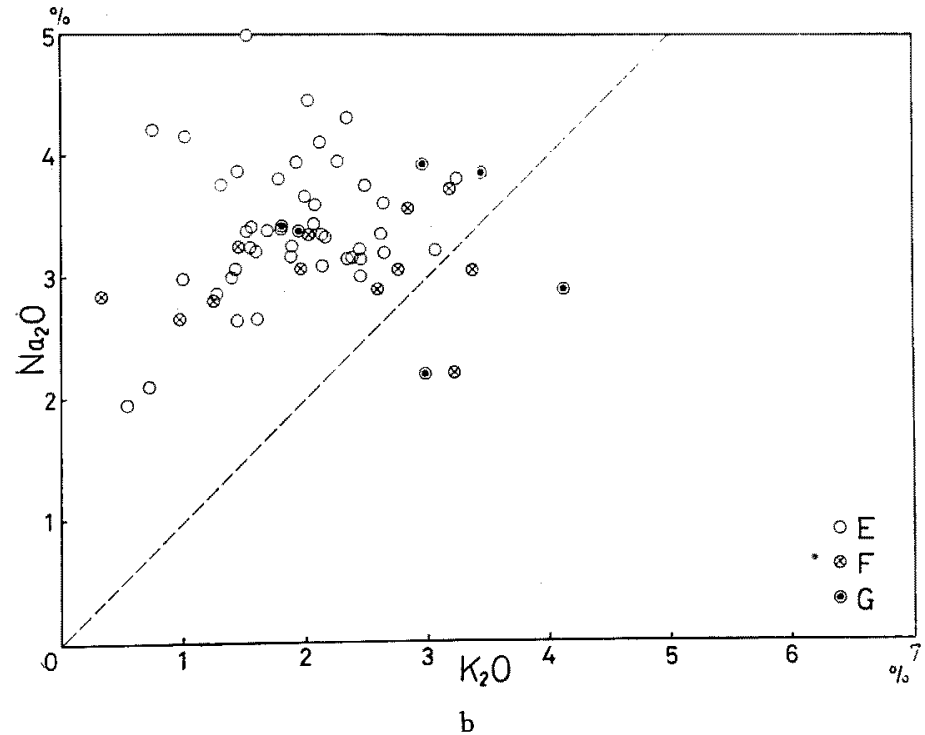

Fig. 3. $\mathrm{K}_{2} \mathrm{O}-\mathrm{Na}_{2} \mathrm{O}$ diagrams. 


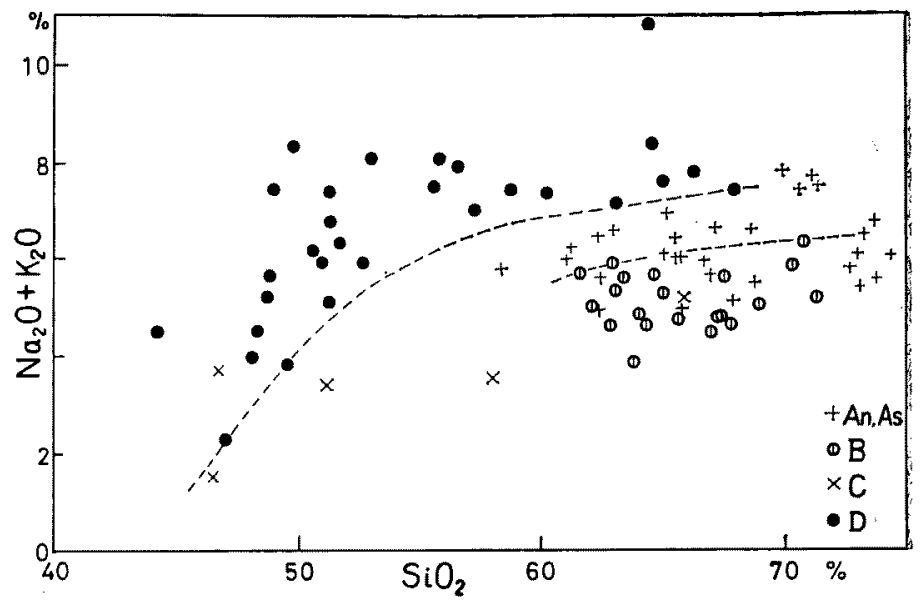

a

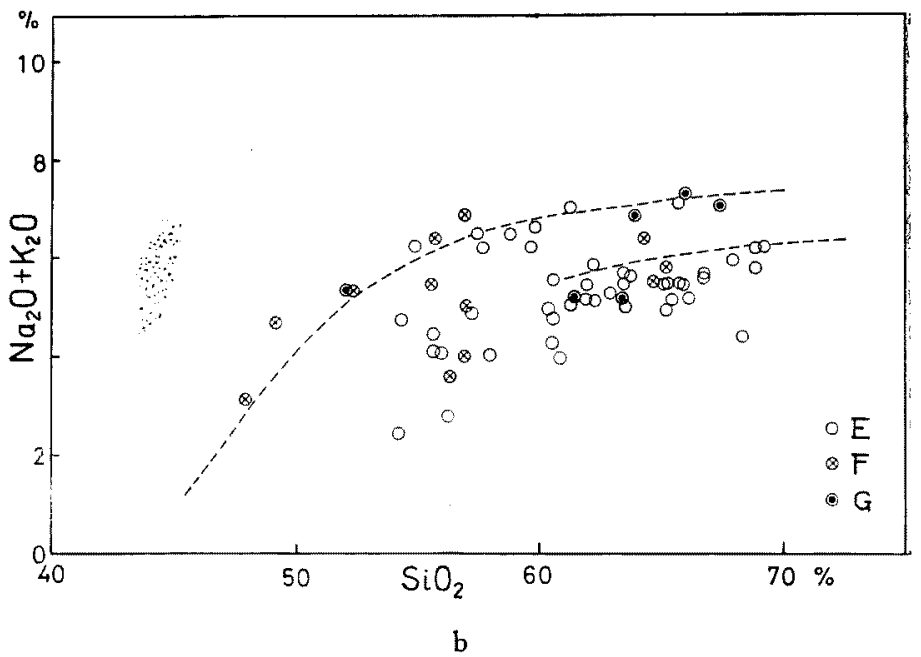

Fig. 4. $\mathrm{SiO}_{2}-\left(\mathrm{Na}_{2} \mathrm{O}+\mathrm{K}_{2} \mathrm{O}\right)$ diagrams. 
公表資料は Kozu (1914)，山根 (1915)，近藤 (1930)，滛辺 (1950)，Yamada (1953)， Shibata.Okada (1954，1955), 石井·他 (1955), 長谷川 (1955), Shibata (1956), 大 和 (1956)，岡田 (1956), Seki (1957), Shibata et al. (1958, 1960), 神戸 . 竄津 (1961), Sendo·Ueda (1963)，Onuki·Tiba (1964)，増田・他（1965），柴田（1967）および䖝 沢（1969）による6のである。

なお附表 1 に示した岩石の化学分析值を除く未公表資料は石原舜三（7個），大貫仁.

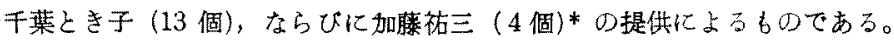

現在のところ，分析試料採取地点はまだかなり偏在している欠点は否定できない。とく

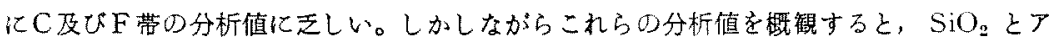
ルカリが最り多様な值を示している。そこでこれらの成分に関する図表にて考祭を行なっ てみる。結果的に言えることは各带の分析值は，ある限定された籍用内に示される場合が 多い。これは前項で述へた区分の妥当性を支持するものといえよう。

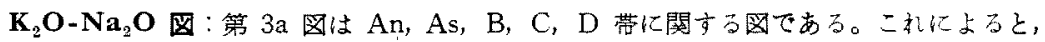
$\mathrm{B}$ 带は $\mathrm{Na}_{2} \mathrm{O}>\mathrm{K}_{2} \mathrm{O}$, D带の大半は $\mathrm{K}_{2} \mathrm{O}>\mathrm{Na}_{2} \mathrm{O}$ で，両者のプロットされる範国は重な らず，きわかて対称的である。また An，As 带は B, D 带の両者のフィールドにまたが

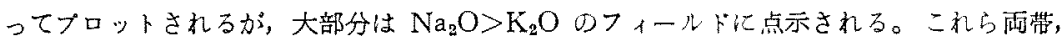

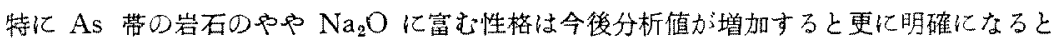
者えられる。

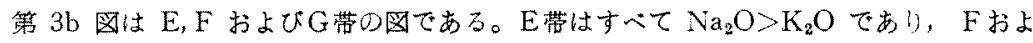
び $\mathrm{G}$ 帯では一部のるのが $\mathrm{K}_{2} \mathrm{O}>\mathrm{Na}_{2} \mathrm{O}$ である。ただ， F带の分析值 12 個のうち，9 個が折壁岩体のbのである。したがってF带は実際よりもアルカリに富む傾向が强調され ている可能性が大きいので注意を要する。このことは以下に述へる図についてる同様であ 万。

$\mathrm{SiO}_{2}-\left(\mathrm{Na}_{2} \mathrm{O}+\mathrm{K}_{2} \mathrm{O}\right)$ 图：この図は火山岩の分類にしばしば利用される(第 $4 \mathrm{a}, \mathrm{b}$ 図)。 アルカリに富む傾向をもつものから，D-An，As，E-B 带の3者が区別される。F，G 図は前因と同様に，E带とほぽ同じ傾向をもつが，一部はD带のフィールドにプロトさ れる。

ノルム Q-(Ab+An)-Or 図：この図は，花崗岩質岩類の分類によく用いられるモー ト石英一斜長石一カリ長石図をノル么值で表現したものである(第5図)。これらの2つの 図では，An+As，B，C，D， E，F， G の各带がそれそれ若干重なっているが，各々の フィールド持っていることが判断できる。分析值のそしい C F F およでG带を除くとし ても，各帯はかなりまとまったフィールド内に示されている。

ノルムQ-Ab-Or 図：この図に全分析值をブロットすると，やはり第 $4 \mathrm{a}, \mathrm{b}$ 図と同 程度に各带が区分される。しかしここで住簡略化して $\mathrm{Q}+\mathrm{Ab}+\mathrm{Or}>70 \%$ のものだけを

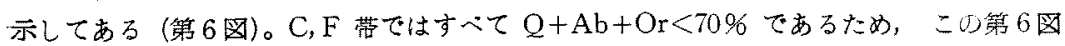

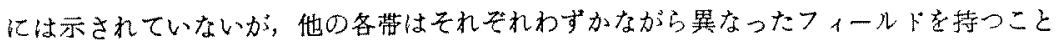
がわかる。

* このうち 2 個は本会誌， 65 巻に揭載の予定。石島正巳 ·加藤祐三 (1971)，北上山地， 折壁花楀岩臀岩体について。 

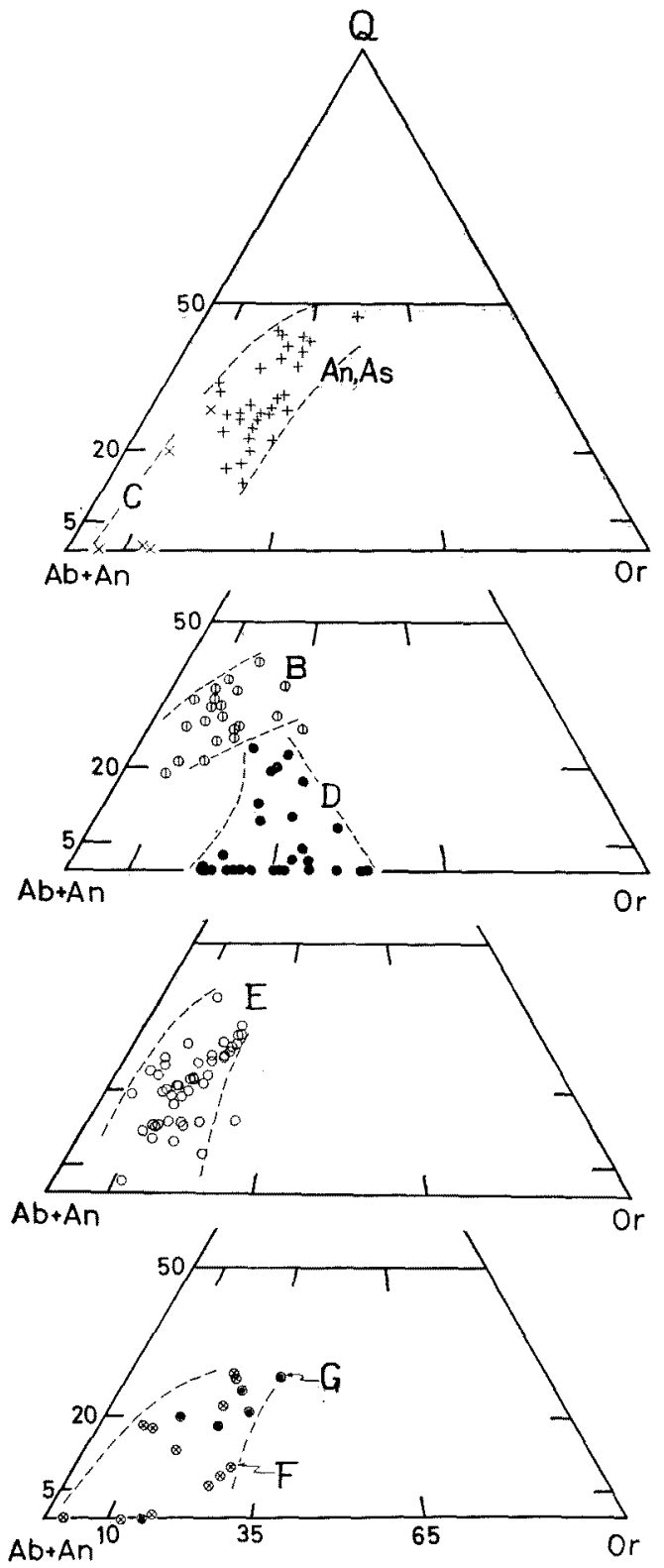

Fig. 5. $Q-(A b+A n)-O r$ triangular diagrams. 


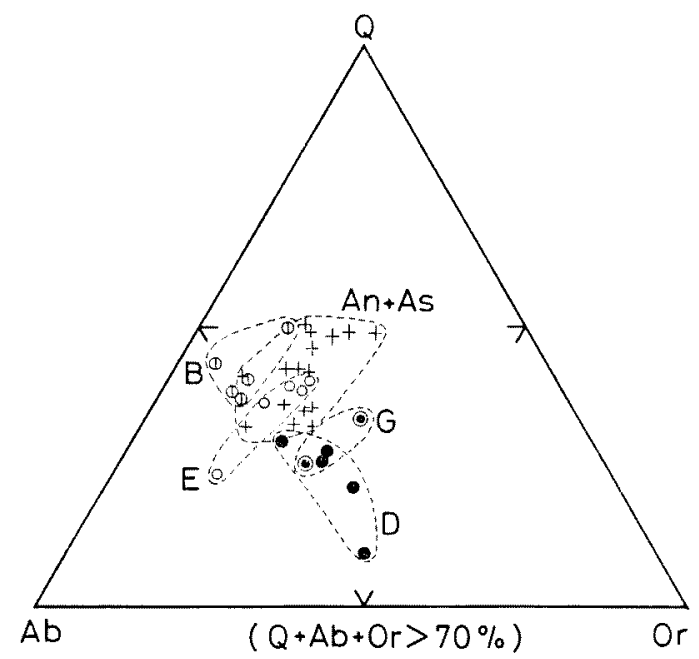

Fig. 6. Q-Ab-Or triangular diagram.

\section{4.おわりに}

今まで述へてきたように種々の資料を絴括してみると，北上山地の花崗岩貿岩類を 8 带 に区分することはかなり合理的のように思われる。これら8带が各々，白平紀花崖岩筫岩 類の活動の一端を示すことは当然であるが, 大きくみて, 南, 北の 2 つグルーブにわけ て考えるここはで委る。しかしながら，南北の效立の傾向加うかがえるにしても，これら

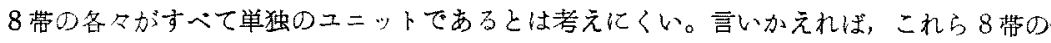
いくつか纳本来連䌇する带であったり，近縁性をもつ带である可能性がある。事実上，上 記の諸項で As 带之An带の連続性を考虑にいれて記述してきた。そこで, 此較的近縁 性のあると考えられる带を拾いだしてみることにする。

ま方 An 带とAs 带は，

1)，北上山地東縁に沿っており，しかも中生層分布地域に位置している。

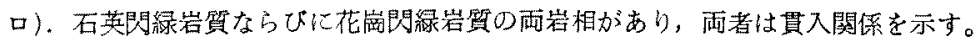

八). 花菵聞緑岩は花崗斑岩に移化する。

二)、プロトクラスチック組織を示す部分がある。

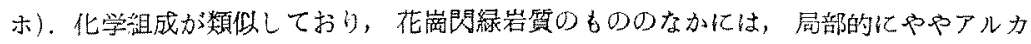
リに富んだ岩椙がみられる。

へ)、接触变成带の幅がせまい。

などの類似点があり，これらから考えると一連のちのと是なしても不自然ではないだるう。 これらが An ( $\mathrm{n}=$ north), As ( $\mathrm{s}=$ south) と名付けた理由である。

またC带とF带は，雨者とも

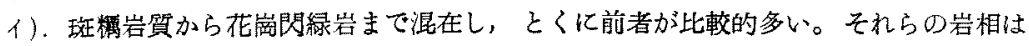


Table 1. Characteristic features of several zones in the Kitakami granitic rock province.

\begin{tabular}{|c|c|c|c|c|}
\hline Zone & Chief constituent rocks* & Occurrence & $\begin{array}{l}\text { Rock facies } \\
\text { change }\end{array}$ & Alkali content \\
\hline An & Quartz-diorite, granodiorite, (granite) & \multirow{2}{*}{$\begin{array}{l}\text { Intruded in Mesozolic region, } \\
\text { shallow intrusive type, } \\
\text { partially protoclastic. }\end{array}$} & \multirow{2}{*}{ Distinct } & \multirow{2}{*}{$\begin{array}{l}\text { Mainly } \\
\mathrm{Na}_{2} \mathrm{O}>\mathrm{K}_{2} \mathrm{O}\end{array}$} \\
\hline As & Quartz-diorite, granodiorite, adamellite & & & \\
\hline $\mathrm{B}$ & Granodiorite, quart $z$-diorite & Younger than An and $C$ zones & Poor & $\begin{array}{l}\mathrm{Na}_{2} \mathrm{O}>\mathrm{K}_{2} \mathrm{O} \\
\text { low alkalies }\end{array}$ \\
\hline $\mathrm{C}$ & $\begin{array}{l}\text { Granodiorite, quartz-diorite, adamellite, } \\
\text { gabbro, (diorite, monzo-diorite) }\end{array}$ & \multirow{2}{*}{$\begin{array}{l}\text { Small rock bodies, } \\
\text { shallow intrusive type }\end{array}$} & \multirow{2}{*}{ Remarkable } & \multirow{2}{*}{$\begin{array}{l}\text { Mainly } \\
\mathrm{Na}_{2} \mathrm{O}>\mathrm{K}_{2} \mathrm{O}\end{array}$} \\
\hline$F$ & $\begin{array}{l}\text { Granodiorite, quartz-diorite, gabbro, } \\
\text { (quartz-monzonite, monzo-diorite) }\end{array}$ & & & \\
\hline $\mathrm{D}$ & $\begin{array}{l}\text { Adamellite, quartz-monzonite, granodiorite, } \\
\text { (kentallenite, pyroxenites) }\end{array}$ & \multirow{2}{*}{ Small rock bodies } & \multirow{2}{*}{ Remarkable } & $\begin{array}{l}\mathrm{Na}_{2} \mathrm{O}<\mathrm{K}_{2} \mathrm{O} \\
\text { high alkaljes }\end{array}$ \\
\hline G & $\begin{array}{l}\text { Granodiorite adamellite, quartz-monzonite, } \\
\text { (monzo-diorite, monzo-gabbro, diorite) }\end{array}$ & & & $?$ \\
\hline $\mathrm{E}$ & $\begin{array}{l}\text { Quartz-diorite, garanodiorite, } \\
\text { (adamellite, gabbro) }\end{array}$ & Relatively large rock bodies & $\begin{array}{l}\text { Different in } \\
\text { each sub-zones }\end{array}$ & $\mathrm{Na}_{2} \mathrm{O}>\mathrm{K}_{2} \mathrm{O}$ \\
\hline
\end{tabular}

* ( ) : Small amount. 
ひとつの岩体内部でも哇げしく変化する。

口)，此較的大型の岩体では周辺部，小型の岩体では全体がしばしば半深成岩貿（玢岩 質)である。

八，折壁岩体以外でも，一部の岩体はアルカリに䈏む䇹相を含む。 という共通した性賏を示している。

また，D，G带は

1), 北上山地西緑份作する。

口). $\mathrm{SiO}_{2} \%$ D. 1. などからみて，非常に幅の広い岩相变化を示す。

八)。ほとんど全㩐成岩類はアルカリに富み，とくに $\mathrm{K}_{2} \mathrm{O}>\mathrm{Na}_{2} \mathrm{O}$ の岩石が多い。 などの共通した性格を持っている。

以上の点からみて，C带はF带に，D带はG带に，E带をへだててそれぞれ連続する可 能性がある。もしそうだとするならば，南部ではB带が久放ていることになる。B带と他 の带との境界は野外でも，鏡下でも，他の各央の境界に比較してもっとも明確である。他 の带との不連繶性のむっとも著しい带といってもよいであるう。

これらの各带の特徴を第1表に示した。この上うな各带の差は，マグマ発生時から鿓入， 固䑩までの間の化学・物理的条件の差を反映していると考えられる。もしそうだをると， 区分を可能にさせた第1の要因としては，現在の貫入位置に近い所でなく，地下㳭所です でに差があったことであろう。第 2 の要因としては，発生時から固結までの間に，マグマ が大きな㩲乱作用一混合作用を受けな加たということか考えられる。恐らく，領家・阿 武隈带のような、变成带の花崗岩類、でなかったことが，区分を可能にさせた要因のひと

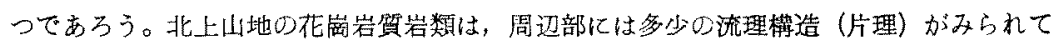
も，中心部には一般に認かられないのもその蓑つけとなるであろう。したがってここで試 みられたような区分は，花嵐岩質岩類の地㲄深所における举動の研究をすすめていく上に， ひとつの重要な基礎凅料になるものと考えられる。

しかしながら，筆者等の区分は現在に占けるひとつの作業仮説である。詳紬な研究が今 後すすめられ，資料の蓄橡の增大にともない当然，加筆，訂正が行われるべきものである 引。

\section{謝辞}

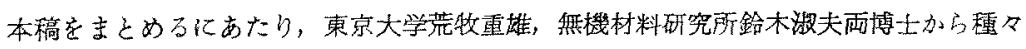
の监教示をいただき，また貴重な資料を御恵与いただいけ。厚く感謝の意を表する。

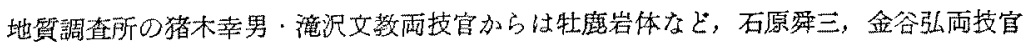
からは本文中の A，E 带の諸岩体，神户信和技官からは石卷周辺の諸岩体，吉田尚技官 からはC带北部の関する資料を御提倛いただいた。また大森江い，大森貞子雨技官には本 稿のために化学分析をしていただいた。梁く謝意を表する次第である。

東北大学，植田良夫教授からは平常御鞭達をいたたいており，深甚なる感謝を述へたい。 
Appendix

Table 1. Chemical compositions

\begin{tabular}{|c|c|c|c|c|c|c|c|}
\hline \multirow{2}{*}{$\begin{array}{c}\text { Zone } \\
\text { No. }\end{array}$} & \multicolumn{4}{|c|}{ An } & \multicolumn{3}{|c|}{ C } \\
\hline & 1 & 2 & 3 & 4 & 5 & 6 & 7 \\
\hline $\mathrm{SiO}_{2}$ & 58.41 & 63.02 & 62.51 & 65.66 & 41.19 & 43.82 & 46.49 \\
\hline $\mathrm{TiO}_{2}$ & 0.69 & 0.66 & 0.66 & 0.47 & 1.28 & 0.63 & 0.51 \\
\hline $\mathrm{Al}_{2} \mathrm{O}_{3}$ & 15.31 & 16.31 & 15.89 & 15.96 & 15.07 & 27.26 & 15.44 \\
\hline $\mathrm{Fe}_{2} \mathrm{O}_{3}$ & 1.54 & 3.40 & 2.11 & 1.61 & 8.35 & 3.75 & 1.35 \\
\hline $\mathrm{FeO}$ & 5.49 & 3.08 & 3.90 & 3.03 & 7.40 & 3.28 & 9.78 \\
\hline $\mathrm{MnO}$ & 0.10 & 0.07 & 0.11 & 0.08 & 0.18 & 0.08 & 0.19 \\
\hline $\mathrm{MgO}$ & 4.32 & 1.86 & 2.23 & 1.61 & 8.26 & 3.03 & 10.40 \\
\hline $\mathrm{CaO}$ & 6.73 & 4.06 & 5.15 & 4.65 & 15.97 & 15.05 & 12.51 \\
\hline $\mathrm{Na}_{2} \mathrm{O}$ & 2.91 & 3.66 & 2.89 & 2.89 & 0.88 & 1.45 & 1.10 \\
\hline $\mathrm{K}_{2} \mathrm{O}$ & 2.83 & 2.87 & 2.68 & 3.09 & 0.32 & 0.47 & 0.42 \\
\hline $\mathrm{H}_{2} \mathrm{O}+$ & 1.25 & 0.65 & 1.65 & 0.93 & 0.77 & 0.94 & 0.88 \\
\hline $\mathrm{H}_{2} \mathrm{O}-$ & 0.26 & 0.19 & 0.19 & 0.05 & 0.21 & 0.24 & 0.22 \\
\hline $\mathrm{P}_{2} \mathrm{O}_{5}$ & 0.21 & 0.22 & 0.19 & 0.15 & 0.04 & 0.08 & 0.07 \\
\hline Total & 100.05 & 100.05 & 100.16 & 100.18 & 99.92 & 100.08 & 99.36 \\
\hline $\mathrm{Q}$ & 9.32 & 19.04 & 19.94 & 23.56 & - & - & - \\
\hline$O_{\Gamma}$ & 16.72 & 16.96 & 15.84 & 18.26 & 1.89 & 2.78 & 2.48 \\
\hline $\mathrm{Ab}$ & 24.63 & 30.97 & 24.45 & 24.46 & 7.45 & 12.27 & 9.31 \\
\hline $\mathrm{Ne}$ & - & - & - & - & - & - & - \\
\hline An & 20.35 & 18.70 & 22.48 & 21.47 & 36.21 & 66.47 & 35.97 \\
\hline $\mathrm{C}$ & - & 0.33 & - & -- & - & - & - \\
\hline Wo & 4.87 & - & 0.77 & 0.25 & 17.86 & 3.23 & 10.73 \\
\hline En & 10.76 & 4.63 & 5.55 & 4.01 & 7.15 & 1.10 & 12.30 \\
\hline$F_{S}$ & 7.86 & 1.89 & 4.54 & 3.62 & 2.46 & 0.70 & 9.84 \\
\hline$F_{0}$ & - & - & - & - & 9.41 & 4.52 & 9.53 \\
\hline $\mathrm{Fa}$ & - & - & - & - & 1.90 & 1.02 & 5.02 \\
\hline $\mathrm{Mt}$ & 2.23 & 4.93 & 3.06 & 2.33 & 12.10 & 5.44 & 1.96 \\
\hline II & 1.31 & 1.25 & 1.25 & 0.89 & 2.43 & 1.20 & 0.97 \\
\hline $\mathrm{Ap}$ & 0.49 & 0.51 & 0.44 & 0.35 & 0.09 & 0.17 & 0.15 \\
\hline
\end{tabular}

Analysts: 1 4; Hitoshi Onuki, 5 12; Ei Omori and Sadako Omori, 13 and 14; Satoshi Kanisawa.

1: Biotite-hornblende granodiorite, Futago (双子) body, a part of Kuki

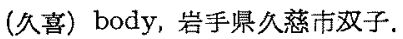

2: Biotite-hornblende granodiorite, Futago body，岩手罧久慈市双子.

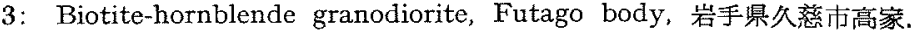

4: Biotite-hornblende granodiorite, Futago body, 岩手県丸户郡種市町有家.

5: Olivine-hornblende-clinopyroxene gabbro, Imoya (伊茂屋) body 岩手 罢九郡山形村伊茂屋山東方.

6: Leucocractic hornblende diorite, Okubo (大久保) body, 岩手県九郡 整米町大久保南方. 
of some granitic rocks.

\begin{tabular}{|c|c|c|c|c|c|c|}
\hline \multicolumn{4}{|c|}{ C } & $F$ & \multicolumn{2}{|c|}{$\mathrm{G}$} \\
\hline 8 & 9 & 10 & 11 & 12 & 13 & 14 \\
\hline 46.75 & 51.19 & 58.04 & 65.84 & 48.00 & 52.30 & 67.46 \\
\hline 0.78 & 0.69 & 0.51 & 0.32 & 0.67 & 0.75 & 0.30 \\
\hline 17.08 & 13.65 & 17.89 & 16.48 & 20.75 & 18.47 & 15.71 \\
\hline 2.28 & 3.36 & 1.82 & 1.85 & 3.17 & 4.37 & 1.99 \\
\hline 7.22 & 5.74 & 5.58 & 2.18 & 6.67 & 4.61 & 1.31 \\
\hline 0.17 & 0.19 & 0.17 & 0.14 & 0.21 & 0.16 & 0.03 \\
\hline 9.32 & 8.41 & 3.00 & 1.47 & 4.93 & 4.07 & 1.37 \\
\hline 11.51 & 11.68 & 7.94 & 5.52 & 10.48 & 8.92 & 3.96 \\
\hline 2.35 & 2.33 & 2.60 & 3.55 & 2.83 & 3.37 & 2.90 \\
\hline 1.32 & 1.05 & 0.94 & 1.60 & 0.35 & 1.94 & 4.11 \\
\hline 0.62 & 0.83 & 1.22 & 0.68 & 1.55 & 1.19 & 0.80 \\
\hline 0.22 & 0.18 & 0.25 & 0.17 & 0.19 & 0.17 & 0.28 \\
\hline 0.36 & 0.18 & 0.18 & 0.12 & 0.17 & 0.32 & 0.22 \\
\hline 99.98 & 99.48 & 100.14 & 99.92 & 99.97 & 100.64 & 100.44 \\
\hline- & 0.50 & 15.40 & 24.87 & - & 1.90 & 25.03 \\
\hline 7.79 & 6.21 & 5.56 & 9.45 & 2.07 & 11.46 & 24.29 \\
\hline 14.47 & 19.71 & 22.00 & 30.04 & 23.95 & 28.51 & 24.54 \\
\hline 2.93 & - & - & - & - & - & - \\
\hline 32.18 & 23.68 & 34.35 & 24.31 & 42.87 & 29.56 & 17.71 \\
\hline- & - & - & - & - & - & - \\
\hline 9.43 & 13.88 & 1.68 & 0.99 & 3.40 & 5.34 & 0.27 \\
\hline 6.08 & 20.94 & 7.47 & 3.66 & 8.77 & 10.14 & 3.26 \\
\hline 2.72 & 6.98 & 8.21 & 2.20 & 6.98 & 3.91 & 0.33 \\
\hline 12.00 & - & - & - & 2.46 & - & - \\
\hline 5.93 & - & - & - & 1.49 & - & - \\
\hline 3.31 & 4.87 & 2.64 & 2.68 & 4.60 & 6.34 & 2.88 \\
\hline 1.49 & 1.31 & 0.97 & 0.61 & 1.27 & 1.42 & 0.57 \\
\hline 0.84 & 0.39 & 0.39 & 0.26 & 0.37 & 0.70 & 0.48 \\
\hline
\end{tabular}

uke (ノソウケ) body, 岩手儤九户郡種市町ノソウケ峠.

8: Olivine-biotite-clinopyroxene gabbro, Tengu (天狗) body, 岩手暴九户郡 㪕米町天狗.

9: Hornblende monzo-gabbro, Hiraniwa (平庭) body，岩手県岩手郡葛巻町東部.

10: Hornblende diorite, Numabukuro (沿袋) body,岩手䍗九户郡山形村沼袋.

11: Hornblende-biotite quartz-diorite, Ushigazawa (牛ガ沢) body, 岩手景 九户郡軽末町牛分沢南方.

12: Clinopyroxene-hornblende diorite, Shimokawauchi (下川内) body, 宫 城景本吉郡本吉町下川内.

13: Clinopyroxene-hornblende monzo-diorite, Rifu (利府) body, 宮城県黒 川郡利府时春日。

14：Hornblende adamellite，Rifu body，宮城景黒川郡利府町春日. 


\section{引用文献}

長谷川修三 (1955)，岩手県東磐井郡大東町興田産コランダム及び区铁柘榴石，岩鈗，

39, $194 \sim 203$.

本間弘次 (1962)，田老・中里産苇青石岩の成因について一その1 概説，地質雜，

$68,1 \sim 16$.

五十嵐俊雄，岛津光夫（1961），日本におけるウランの産状；北上山地の花南岩類と

これらに伴う含ウラン鉱㕅，地調報告，No. 190, 34〜 44.

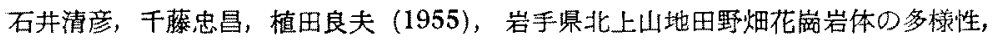

岩鉱，39，177～ 189 .

説明書 II, 岩手詈.

神戸信和，身津光夫 (1961)，5万分の1地筫図幅「気仙沼」および説明書，73，地

質調查所.

蟹沢聡史 (1969)，北上山地の人首花藏閃緑岩体について，岩鉱，62，275２88.

- (1970), 北上山地花厥岩兵岩石の斜長石 そのI，光軸角のバラッキと秩

序度との関你，岩鉱，64，123～129。

河野礼, 植田良夫 (1965), 本邦産火成岩の K-A dating (II) 北上山地の花崗岩

類, 岩鉣, 53, 143 154.

近藤信興 (1930)，陸奥烏越基性岩の泠却史とアルカリ長石の成因に就いて（其一）, 地筫雑, 37，433〜458。

Kozu, S. (1914), Kentallenite with unusual mica from Torigoe, Japan, Sci.

Rep. Tohoku Univ., Ser II, 2, 1 $\sim 5$.

増田紘一，大貫仁，千葉とき子(1965)，北上山地，姫神花厥岩質岩体について，岩

鉱, 54, $62 \sim 75$.

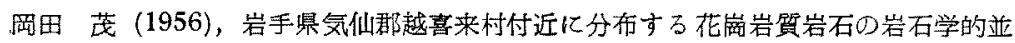
びに岩石化学的研究一岩手県気仙郡越喜来地方の Regional geochemistry そ の 1 一，地貿雑，62，680 687.

Onuki, H. and Tiba, T. (1964), Petrochemistry of the Ichinohe alkali plutonic complex, Kitakami mountainland, northeastern Japan, Sci. Rep. Tohoku Univ., Ser. III, 9, 123 154 .

小貫義男 (1969)，北上山地地質誌，東北大地筫古生物研邦報，No. 69，1２39. 大和栄次郎 (1956)，5万分の1 地質图幅「土淵」および説明亚，16，地質調查所. Seki, Y. (1957), Petrological study of hornfelses in the central part of the median zone of Kitakami mountainland, Iwate Prefecture, Sci. Rep. Saitama Univ., Ser. B, 2, 307 361.

Sendo, T. (1959), Comparison of chemical compositions between the granitic rocks of the Abukuma and Kitakami Massifs, northeastern Honshu, Japan, Sci. Rep. Tohoku Univ., Ser. III, 6, 227 259. and Ueda, Y. (1963), Petrology of the Kinkasan islet, Miyagi 
Prefecture, northeastern Japan, Sci. Rep. Tohoku Univ., Ser. III, 8, 297 315 .

Shibata, H. (1956), Chemical composition of Japanese granitic rocks in regard to petrographic provinces. Part IV. - Petrographic provinces. of eastern Japan - Sci. Rep. Tokyo Kyoiku Dai., Sec. C, No. 41, 1 23.

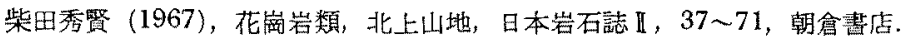

Shibata, H. and Okada, S. (1954), Chemical composition of Japanese granitic rocks in regard to petrographic provinces. Part I, Sci. Rep. Tokyo Kyoiku Dai., Sec. C, No. 22, 141 172.

- and (1955), Chemical composition of Japanese granitic rocks in regard to petrographic provinces. Part II. - Principal elements -, Sci. Rep. Tokyo Kyoiku Dai., Sec. C, No. 31, 141 161.

- _ - and Oki, Y. (1958), Chemical composition of Japanese granitic rocks in regard to petrographic provinces. Part VI. - Principal elements -, Sci. Rep. Tokyo Kyoiku Dai., Sec. C, No. 59, 71 94.

Shibata, K. and Miller, A.J. (1962), Pottassium-argon ages of granitic rocks. from the Kitakami highlands, Bull. Geol. Surv. Japan, 13, 67 69.

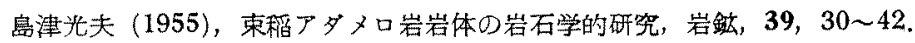
Streckeisen, A.L. (1967), Classification and nomenclature of igneous rocks, N. Jb. Miner. Abh., 107, 144 214.

鉿木淑夫（1958），北上山地の酸性深成岩類，鈴木醇教授還暦部念論文集，316３24。 渡辺万次鄎 (1950)，北上山地の次成活動，地団研専趣，No.4，23.

Yamada, H. (1953), On thermally metamorphosed rocks in Senmaya district, Iwate Prefecture, Japan, Bull. Tokyo Inst. Tech., Ser. B, No. $3,1 \sim 41$.

山根新次 (1915)，20万分の 1 地質図幅「盛网」および説明書，地筫調查所。

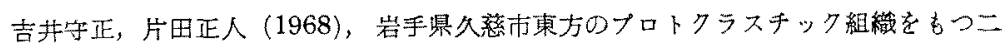
子花菵崖，岩鉱，60，228～ 239 . 